\title{
Correlation Between Hand Grip and Achievement in Indonesian Female Floorball Athletes by Purwo Sri Rejeki
}

Submission date: 06-Feb-2020 10:01AM (UTC+0800)

Submission ID: 1252286018

File name: Grip_and_Achievement_in_Indonesian_Female_Floorball_Athletes.pdf (161.19K)

Word count: 1684

Character count: 9035 


\title{
Correlation Between Hand Grip and Achievement in Indonesian Female Floorball Athletes
}

\author{
Loren Fibrilia Perangin-angin ${ }^{1}$, Siti Maesaroh ${ }^{1}$, Irfiansyah Irwadi ${ }^{2}$ and Purwo Sri Rejeki ${ }^{3}$

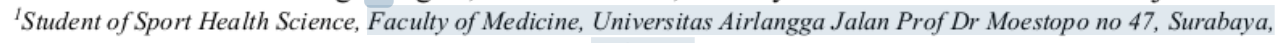 \\ Indonesia \\ ${ }^{2}$ Department of Physiology, Faculty of Medicine, Universitas Airlangga, Surabaya, Indonesia \\ ${ }^{3}$ Department of Physiology, Sport Health Science Program, Faculty of Medicine, Universitas Airlangga, Surabaya, \\ Indonesia \\ purwo_faal@yahoo.com,purwo-s-r@fk.unair.ac.id
}

\begin{abstract}
Keywords: $\quad$ Achievement, Female, Floorball, Hand Grip, Indonesian Athletes.
Abstract: $\quad$ Floorball is a sport that is played using a stick. One of the skill that a player needs is hand grip. The aim of this research is to understand the relation between hand grip and achievement in Indonesian female floorball athletes. This research was performed by observational analytic design. The subjects of this study were 38 female floorball semi-finalists at the national championship Dekan Cup Unesa II in 2017. The subjects were aged 16-31 years old. The result of the hypothesis test proves that there is no correlation between hand grip and achievement in Indonesian female floorball athlete.
\end{abstract}

\section{INTRODUCTION}

Floorball is a sport that was developed in Sweden and that has been played since the mid-1970s Floorball was first played in Indonesia in 2010 (IFA, 2010). According to the Indonesian Floorball Association (IFA), at Southeast Asian-level competition, Indonesian female floorball athletes got a bronze medal at the Myanmar SEA Games. The following year, Indonesian floorball athletes won bronze medals in the male and female categories at the Southeast Asia Championship in Singapore. In 2017 the Indonesian team came fourth at the Men's Asia Floorball Championship in Thailand. She results indicate that this sport has the potential to be developed to help Indonesian sporting accomplishment at the international level. Physical condition is one of the requirements that are needed to increase what can be achieved by an athlete, it can even be said to be a basic necessity that cannot be delayed (Sudarmono, 2007). Physical condition development is needed in floorball sports to enable maximum performance in the field.

The dominant physical condition components in floorball include speed, flexibility, aerobic endurance, and agility (Agustin, 2017). According to the International Floorball Federation (IFF), a good floorball player must have motor skills, speed, endurance, strength, agility, ball control, passing skills, mental capacity, and different roles in game play (Oksanon, 2017). In passing skills, hand grip is necessary for the floorball player in holding the stick in order to be accurate and control the strength when making a pass. An explanation of anthropometry and the impact of hand grip strength on players who had achieved in a competition had never been done before. Knowledge of anthropometry and hand grip for Indonesian female floorball athletes will be quite important in providing a description of potency and a reference for athletes and coaches in this sport. This research will investigate the correlation between hand grip and achievement in Indonesian female floorball athletes.

\section{METHODS}

\subsection{Research Design}

This research was conducted by analytic observational design with cross sectional observation. The research objectives were achieved

238

Fibrilia Perangin-angin, L., Maesarah, S., Irwadi, I. and Sri Rejek, P.

Correlation Between Hand Grip and Achievement in Indonesian Female Floorball Athletes. In Proceedings of Surabaya International Physiology Seminar (SIPS 2017), pages 238-240 ISBN: 978-989-758-340-7

Copyright $@ 2018$ by SCITEPRESS - Science and Technology Publicafions, Lda. All rights reserved 
by measuring the anthropometry of height, body weight, leg length, sitting height, and hand grip in relation to the achievement result.

\subsection{Research Subjects}

The subjects of this research were female floorball semi finalists at the national championship Dekan Cup Unesa II in 2017. The subjects were 38 females aged 16-31 years old.

\subsection{Anthropometric Measurement}

Body weight was measured using body scales. Height, sitting height, and length of leg were measured using tape portable.

\subsection{Hand Grip}

Hand grip was measured using a grip strength dynamometer. The measurement procedure was carried out by asking the athlete to stand upright with the foot in an open position as wide as the shoulder. The hand was holding the grip strength dynamometer straight at the side of the body. The palms were facing the thighs, while the dynamometer scale was facing outwards. The grip strength dynamometer was squeezed as tightly as possible. The hand that was holding the grip strength dynamometer could not be in contact with other objects. The squeezing results could be seen on the dynamometer scale.

\subsection{Achievement Results}

Achievement results in this championship were first, second, third, and fourth positions. To facilitate the statistical analysis, the result was converted as follows: 1st position was awarded 100 points, 2nd position was given 75 points, 3 rd position was given 50 points, and 4 th position was awarded 25 points.

\subsection{Data Analysis}

Data was analyzed using SPSS to present the descriptive distribution, a Oneway ANOVA test to get the mean comparison, and a Pearson correlation test to measure the relationship between variables.

\section{RESULTS}

The characteristics of the research subjects can be seen in table 1. The height range of the subjects was $145-168 \mathrm{~cm}$. The body-weight range was $39-68.5$ $\mathrm{kg}$. The age range was $16-31$ years. The leg-length range was $89-97 \mathrm{~cm}$. The right-hand-grip range was $15.7-36.1 \mathrm{~kg}$, while the left-hand-grip range was $18.4-33.2 \mathrm{~kg}$. The sitting-height range was $77-90$ $\mathrm{cm}$.

Table 1: The research subjects' characteristics.

\begin{tabular}{c|c|c}
\hline Variable & $\mathrm{N}$ & Mean \pm SD \\
\hline Height $(\mathrm{cm})$ & 38 & $157.74 \pm 5.74$ \\
Body weight $(\mathrm{kg})$ & 38 & $53.78 \pm 8.90$ \\
BMI & 38 & $21.53 \pm 2.76$ \\
Age (year) & 38 & $20.79 \pm 3.24$ \\
Leg length $(\mathrm{cm})$ & 38 & $91.14 \pm 3.79$ \\
Right grip $(\mathrm{kg})$ & 38 & $26.73 \pm 4.21$ \\
Left grip $(\mathrm{kg})$ & 38 & $26.22 \pm 4.01$ \\
Sitting height $(\mathrm{cm})$ & 38 & $82.99 \pm 3.40$ \\
\hline
\end{tabular}

To reach the research objectives, a correlation test was performed for the overall variables. The result of the correlation test can be seen in table 2 .

Table 2: Correlation.

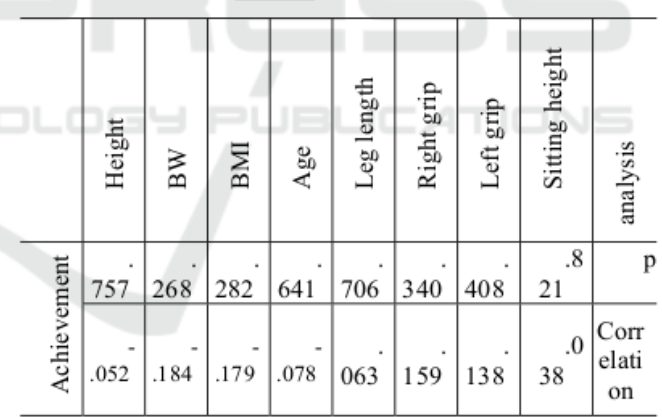

\section{DISCUSSION}

\subsection{Characteristics}

Floorball is a type of floor hockey played on an indoor field sized $20 \times 40 \mathrm{~m}$, where two teams that consist of six players (one goalkeeper, two defenders, and three forward players) try to score a goal against the opponent (Angel, 2013). Floorball is a quick game that is played for three periods of 20 minutes each without excessive body contact (Pasanen et al., 2008). Floorball sports training is 
related to chronological age. The link between sports chronological age based on the Canadian model and the Long Term Athletes Development (LTAD) model suggests that athlete training is divided into seven stages: stage 1- Action Kids ( $0-5$ years old); stage 2-Fundamental (6-9 years old); stage 3-Learn to practice (9-12 years old); stage 4-Exercise to practice (12-16 years old); stage 5-Exercise to compete (16-18 years old); stage 6-Exercise to win (18+ years old); and stage 7-7-Pension or rest (Nurjaya, 2009). Physiologically, peak performance is achieved at stage 6 , the age of $18+$, because at this stage skills, speed, stamina, and strength are continuously improved to get maximum performance (Nurjaya, 2009). Meanwhile, based on the research, Nurhidayah (2013) stated that in sports such as hockey, the firing power of the penalty time is affected by arm muscle power, grip strength, wrist flexibility, and hand grip, which contribute to the ability to shoot by $85.20 \%$, while leg strength contributes most to the ability to shoot compared with arm muscle power, grip strength, and wrist flexibility. Table 2 shows no significant correlation between height, body weight, age, leg length, sitting height, or hand grip and achievement result. The average height of the subjects was $157.74 \pm 5.74 \mathrm{~cm}$, while that of international female athletes is $81.6 \pm$ $8.6 \mathrm{~cm}$ (Karlson, 2015). The mean of body weight of the subjects was $53.78 \pm 8.90$, while that of international female athletes is $7.7 \pm 15.6$ (Karlson, 2015). The mean of BMI of the subjects was $21.53 \pm$ 2.76 , while the average BMI of international female athletes is $6.4 \pm 3.1$ (Karlson, 2015).

\section{CONCLUSION}

There is no correlation between height, body weight, age, leg length, sitting height, or hand grip and achievement results. It could be that in addition to these factors, floorball achievement results are influenced by leg muscle strength (Nurhidayah, 2013) and social factors between people (Suryabrata, 2002)

\section{REFERENCES}

Agustin, Dini dan Soni Sulistyarto. 2017. Analisis Kondisi Fisik Atlet Putri Floorball Universitas Negeri Surabaya. Jurnal Kesehatan Olahraga Vol. 05 No. 02 Tahun 2017, Hal 29-36
An. 2010. Grand Launching Floorball di Indonesia dalam http://floorball.or.id accessed on 9 September 2017, 11.30

Angel, Miguel et al. 2013. Ball Possession Effectiveness in Men's Elite Floorball According to Quality of Opposition and Game Period. Journal of Human Kinetics volume 38/2013, 227-237

Karlson, Kelli A. 2015. The Relationship Between Bmi And Body Composition In Collegiate Athletes. Tesis dari Illinois State University.

Nurhidayah, Efi. 2013 .Sumbangan Power Otot Lengan, Kekuatan Genggaman, Fleksibilitas Pergelangan Tangan, dan Kekuatan Tungkai Terhadap Kemampuan Tembakan Penalti pada Hockey. Skripsi Jurusan Ilmu Keolahragaan. FIK Universitas Negeri Semarang.

Nurjaya, Dede R. 2009. Tahapan Pembinaan Atlet Jangka Panjang. sPenataran Pelatih Cabang Olahraga Dayung" pada Pengda (Pengurus Daerah), PPLP (Pusat Pembinaan dan Latihan Olahraga Pelajar), PPLM (Pusat Pembinaan dan Latihan Olahraga Mahasiswa) dan Perguruan Tinggi Se-Indonesia, Surabaya 24-27 Mei 2009

Oksanon Jari. 2017. Floorball Youth Start Up Kit. International Floorbal Federation.

Pasanen K, Parkkari J, Kannus P, Rossi L, Palvanen M, Natri A, Järvinen M. Injury risk in female floorball: a prospective one-season follow-up. Scand J Med Sci Sport, 2008; 18: 49-54

Sudarmono. 2007. Kondisi Fisik Atlet Hockey Tim Jawa Tengah Tahun 2007. Skripsi dari FIK Universitas Negeri Semarang

Suryabrata, S. (2002). Psikologi Pendidikan. Jakarta : Rajawali. 
Correlation Between Hand Grip and Achievement in Indonesian Female Floorball Athletes

ORIGINALITY REPORT

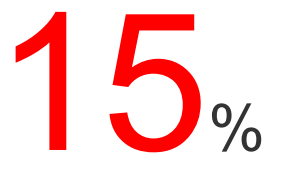

SIMILARITY INDEX
$13 \%$

INTERNET SOURCES
$8 \%$

PUBLICATIONS
$2 \%$

STUDENT PAPERS

\section{PRIMARY SOURCES}

1 content.sciendo.com

Internet Source

2 Miguel-Ángel Gómez, Miguel Prieto, Javier

Pérez, Jaime Sampaio. "Ball Possession

Effectiveness in Men's Elite Floorball According

to Quality of Opposition and Game Period",

Journal of Human Kinetics, 2013

Publication

3

file.upi.edu

Internet Source

4 repository.unair.ac.id Internet Source

5 id.123dok.com

Internet Source

6 jurnalmahasiswa.unesa.ac.id 
Exclude bibliography

On 
Correlation Between Hand Grip and Achievement in Indonesian Female Floorball Athletes

FINAL GRADE

$/ 100$

PAGE 1

PAGE 2

PAGE 3
GENERAL COMMENTS

Instructor 